\title{
ETHNIC DIVERSITY OR ETHNIC DISINTEGRATION FOR THE EXISTENCE OF A CONTEMPORARY CONFLICT
}

\author{
by Jarosław J. Piatek
}

In many analysis of contemporary military conflicts, their ethnicity is emphasized. Ethnic dissimilarities are indicated as the main element which causes diversity leading to even very dramatic events. For some people dissimilarity is a possibility of marginalization, for others a possibility of arousing some values which nowadays are very often treated as secondary. Ethnicity has a changeable character resulting from the process of its settling. It cannot be seen according to the rights characteristic for former processes. To what extend does the category change in the contemporary world? Isn't it used only in order to hide a lack of communication and reluctance to compromises? Isn't ethnicity manipulated by polititians, very often temporarily understanding interest of people communities, who because of very low reasons oppose symbolism of ethnicity to arising processes of modernization? Or maybe ethnicity is another "magic charm" which we use so easily sitting in a "quiet" of a political stability. The process which can be easily placed in universalism and hardly in rationalism. 


\section{ETHNICITY IN THE PROCESS OF CHANGES}

Certainly it would be a truism to state that a base of conflicts, also the armed ones, hardly ever is a single problem. Most often it is a series of various issues having classic conditionings and those falling into a sphere of political, economic and ideological actions. ${ }^{1}$ It could appear that the close of the century, being "the end of a history", released another factor starting conflicts. Ethnicity which for some people enters "salons of history" because of a divorce of the Czechs and the Slovaks and tragedies taking place among the former Yugoslavians, Chechens, Georgians, Kurds and many more. Ethnicity which is seen as a way to unify Germans and Europeans. On the one hand, tragedies with respect to individual as well as group choices between one evil which is war and the Four Horsemen of the Apocalypse accompanying it and another evil which becomes a basis of a "good" independence. On the other hand, progress, modernization, openness and space not limited by isms. At the basis of separatist strivings there is a disintegration of multiethnic countries, economic situation, a fight for natural resources or a lack of acceptance of existing authorities. But there are also rights of historical, territorial, economic character and the ones connected with diaspora's influence. Observation of contemporary ethnic relations can indicate that in the sphere of connections, identities and actions of ethnic groups, there are deep changes which have a huge influence on presented aspects. Almost $1 / 4$ of Europe's territory can be a subject of conflicts which can result from ethnic reasons. Many states of the region are not free from various myths about a greatness and superpower and, basing on it, chimeras promoting necessity of reviving the greatness of the Great Albania, Macedonia, Bulgaria, Serbia, Croatia, Hungary and Romania arise. ${ }^{2}$ Don't we now, when so often we have to

1 See further about factors causing wars and armed conflicts among others: R. Artymiak, Wojny i konflikty w XX wieku, [in:] Konflikty współczesnego świata, R. Borkowski (ed.), Cracow 2001, p. 42; Z. Cesarz, E. Stadtmüller, Problemy polityczne współczesnego świata, Wrocław 2002, pp. 80-90; J. Piątek, Wojny XX wieku, Poznań 2009.

2 Spory i konflikty międzynarodowe. Aspekty prawne i polityczne, W. Malendowski (ed.), Wrocław 1999, pp. 348-349. 
verify our views, when so often relativism comes to the fore, surrender too often to "acting in the mist" in ethnic issues?

\section{POLITICIZATION OF CULTURE}

Direct connection between culture and politics manifests in a culturally constructive role of politicians. The meaning of this connection, in process of coming into being of nations, in its genealogical ethnic version has been noticed by Anthony D. Smith. ${ }^{3}$ In contrast to territorial civil model, typical for western societies, turning into nation does not occur by dissemination of a culture of ethnic aristocracy with help of a bureaucratized state. In democratic states, in a fight for precise rights, privileges and material goods, ethnic groups use the argument of their own cultural specificity, peculiar connection with a particular territory based on their origin.

Ethnic culture has become a weapon in a political fight. The educated intellectuals and intelligentsia give ethnic groups, gathering all social classes around common traditions, new values which motivate to create a political nation. ${ }^{4}$ Elements of traditional social bonds based on common origin, history, types of economy and many other cultural features are becoming a severe material subjected to a treatment by contemporary

3 Smith claims that nationalism bases on a former, historical concept of "a group", contemporary it is a kind of method to feel a common identity and the common past. He says that many nationalisms are the consequences of historically incorrect interpretation of events from the past and they tent to mythologize small, inaccurate pieces of their history. Nationalism, according to Smith, does not mean that members of a nation should be entirely similar but they should feel an intensive bond of solidarity with each other as a nation. In that way the sense of nationalism is not connected with a bonding ideology or even a territory. Nationalism bases on already existing relationship, religion and beliefs. Smith describes ethnic groups which create a background of modern nations as "ethnies". Speaking of national states Smith notices "terms of a state of national country". We can speak of national country only when ethnically and culturally homogeneous population lives in borders of a state and the borders coincide with borders of its ethnicity and culture. Such criterions are met by less than $10 \%$ of existing countries.

4 Florian Znaniecki introduced a term „cultural leaders”, further: F. Znaniecki, Wspótczesne narody, Warsaw 1990, p. 74. 
ideologists. They create a national ideology and, in consequence, a modern nation. Ethnicity is consequently becoming a bargaining card, just a merchandise. Possessing by a group a status of a nation or an ethnic group gives it specific privileges, it becomes a political subject which has specific rights acknowledged internationally and locally.

Ethnic culture is becoming a tool in a concrete political fight. Politicians, accomplishing these tasks with their activity, often understand it as creating or reconstructing ethnos or nation in accordance with a constructed by them project. In activity of ethnic ideologists, individuality of one's own culture is emphasized and some elements are rescued from oblivion and established as symbols and characteristics of a group. In case of its collapse or a radical impoverishment, the ideologists demand creation of proper conditions for ethnic tradition's revival.

A huge meaning for a development of modern ethnicity have changes of civilization spreading in the world which all societies surrender to.

It is considered that the French Revolution started a period in which people began to associate a nation with a country and to promote watchwords so that every country was a nation and so that there was no nation included it another country and no countries made of different nations. ${ }^{5}$ Contemporary in accordance with this rule, even that a nation and a country are something totally different, there is a common belief of their strict connection. ${ }^{6}$ A national state is an element of contemporary, political organization of the world.

The basis of coming into being of most European countries were ethnic groups, cultural and language communities. Equating a political community with an ethnic group has led to a situation that national minorities living at the territory of a country were being assimilated or displaced. As a practice showed, a total national uniformity in particular countries has never been reached. In most of the contemporary states, occurrence of

5 Mill used to think that "generally it is an essential condition of free institutions that boundaries of governing coincide with boundaries of nationalities", further: J. St. Mill, O wolności, [in:] J. St. Mill, Utylitaryzm, trans. M. Ossowska, Warszawa 1959, p. 130.

${ }^{6}$ Naród, [in:] Leksykon Politologii, a joint publication, A. Antoszewski \& R. Herbut (eds.), Wrocław 2004, s. 243. 
smaller or larger national minorities emphasizing stronger or weaker their identity can be seen.

So an ethnic group of a nation has a political as well as cultural character. Possessing by a group a status of a nation or an ethnic group gives it specific privileges, it becomes a political subject which has specific rights acknowledged internationally and locally. ${ }^{7}$ Today many nations using demands of democratic states, propagating slogans of multiculturalism and tolerance, using arguments of human rights introduce to international dialogue an issue of connection of ethnic identity and politics. Pointing to a community in a sphere of local tribal groups or bigger cultural entireties and emphasizing the worth of cultural specificity ever glorifying it, they try to find themselves a proper place in the world of nations. For ideologists "an ethnic culture" which is a tool of a political fight, can include events which limit rights of the others. ${ }^{8}$

\section{ONE AIM AND DIFFERENT METHODS}

Basic aspects connected with ethnic distinctiveness like conviction of language otherness, wider cultural otherness resulting from a connection with a particular territory, history, tradition and even mythology are subjected to technocratic treatments, conscious decisions and intentional actions. There is a radical instrumentalization of human bonds in a sphere of otherness and it is gaining a huge political meaning. Almost whole $20^{\text {th }}$ century was a period of growth of little ethnicities and new "nationalisms", however, its base should be searched for much earlier. Leaders in almost

7 In the 1960s and the 1970s a new phenomenon appeared - movement of indigenous nations which came into being on the tight of defense of different, tyrannized, decolonized and subjected to a social segregation ethnic groups from the western, industrial civilizations.

8 In February 2008, the Albanian majority declared independence of Kosovo which till then has been a Serbian province. Since then ethnic divisions between 2 million Albanians living there and 120 thousand Serbians who stayed there have deepened, [in:] Raport: Kosowo wypędza nieserbskie mniejszości, http://wiadomosci.gazeta.pl/Wiadomosci/1,80607,6656597,Raport_Kosowo_wypedza_nieserbskie_mniejszosci.html (aktualizacja 27 maja 2009). 
every period, often driven by a dislike, arouse hatred and are ready to use their abilities for their own benefit. Actions which for some people have features of great historic events, are very often very calculated, done for manipulation, for reaching political, economic and social aims and for gaining or keeping power. They justify their actions and views with the idea of creating reality in which there is a space only for "the ours".

Against this background there can be conflicts. Out of thirty armed conflicts which have ended recently or are still going on, only ten can be considered as conflicts between civilizations. However, as many as nineteen have been conflicts in the ethnic sphere9."(...) A conflict of interests arising between national states or ethnic minorities and a group of people being a national majority in a given state, alternatively between minorities. They concern above all territorial conflicts, keeping ethnic identity and creating and keeping the existence of a national state. Currently, in most cases, ethnic conflicts concern not so much relations between two countries as relations between ethnic minorities and groups which in a given country are a prevailing majority. That is why it can be assumed that ethnic conflicts have their main source in an ethnic policy of particular national states"10.

The reasons of ethnic conflicts caused by a type of relations in a particular country between a prevailing nationality and minorities living there, can be analyzed on three planes: economic, political and cultural. In many cases the question are values very precious for a given nation, so it is not surprising that undertaken actions heading for their realization take severe forms.

In democratic countries, ethnic group use their cultural specificity and their peculiar connection with a given territory based on the origin, in fight for specific rights. Policies and countries are so stable that they can guarantee demanding those rights in an acceptable time. Liberalization and democratization cause gradual changes in a sphere of ethnicity itself. In postmodern societies, on a certain scale, there take place a proc-

9 J. Piątek, New conditions and changing image of military forces in the early $21 s t \mathrm{c}$. Readiness to unlimited violence?, "Polish Political Science, Yearbook" 2008, XXXVII, p. 33.

${ }^{10}$ Quot after: A. Habrat, Konflikty narodowościowe (wybrane aspekty), [in:] Konflikt i walka, ed. Anna Żuk, Lublin 1996, p. 45. 
ess of individualization and decreasing of the meaning of family bonds (blood - and family connections) and value of an individual begins to be connected not with its affiliation with a given community but with his/her personal features. "(...) says about coming into being a super - or rather extranational and extraethnic form of identity. Ethnic affiliation and nationality does not fall within its sphere at all or it has little meaning. Together with strengthening interethnic contacts, we can be observed the increase of a proportion of individuals who have diverse national or ethnic origin." ${ }^{11}$ However, despite those processes even in some regions of integrating Europe there are quite strong autonomous tendencies. “(...) There is a phenomenon of 'awaking of national awareness' or peculiar "collective awareness.' It used to manifest itself in striving for separation and emphasizing boundaries of a territorial settlement of homogeneous societies. Some national and ethnic groups have contented themselves with a demand of respecting their rights as national minorities', the others have been demanding autonomy. Striving for emerging and stepping out of legal and organizational structures of already existing multinational country or country of a prevailing nation, has been connected with a right to self-determination." 12

Democracy itself is characterized by many strongly emotional behaviors. It relates to free elections, political pluralism and ability to compromise. ${ }^{13}$ It concerns both "ideals and values." The role of ideals in politics is double-edged. Ideals can be an object and a subject of a betrayal. With a great certainty, everyone can define what is and what is not democracy, above all focusing on a concept of democratic rules. They are supposed to consider people's will and are responsible to them. However, a basic problem arises from the analysis, the problem that people rarely agree to what

11 Quot after: E. Nowicka, Świat człowieka - świat kultury. Wydanie nowe, Warszawa 2006, p. 419.

12 Quot after: W. Malandowski, Nowa jakość konfliktów zbrojnych na przełomie XX i XXI wieku. Przyczyny - uwarunkowania - skutki, [in:] Zbrojne konflikty i spory międzynarodowe u progu XXI wieku, W. Malandowski (ed.), Wrocław 2003, s. 19.

13 Sartori as an example distinguishes from prescriptive elements of a concept democracy. Further: G. Sartori, Teoria demokracji, trans. P. Amsterdamski, D. Grinberg, Warszawa 1998, p. 16. 
is the best for them in a given matter. That is why, in practice, democratic rules are the reaction to majority. ${ }^{14}$ In the nature of things, democracy and forms of its rules are not predisposed to solve conflicts in an impartial way. In democracy, there is also a possibility of choosing a side's right which would not be a satisfying choice for everyone.

Creating a strong, healthy, democratic political culture which would be able to survive a hard economic situation, social transformations or a political crisis, requires a lot of time. Not by accident most of the stable democracies in the world belong to a group of the richest countries of the globe while many of the poorest countries have given in to dictatorships or have fallen a victim of a military coup d'état. A task of a democratic country is creating (with a use of political orders) legal frames in which activity of people taking responsibility for themselves, at the same time, makes it possible to support community's interest for their own sake. (...) Political orders have to base on trust of society's members. Trust has to be gained by giving a chance of participation and by legality ${ }^{15}$. Thus, ethnic conflicts are an inherent element of a social life. They could be avoided only if it was possible to create an ethnically homogeneous country.

While analyzing problems of ethnic conflicts, it has to be noticed that manifestations of nationalism are treated differently in Europe and in the United States.

In the USA, nationalism and all nationalist aspirations are considered as a disease requiring elimination at all costs. In many European countries, ethnic diversity of states is approved. However, multiculturalism still causes some problems. ${ }^{16}$ Forming Union the western Europeans expressed a desire to overcome nationalism. However, awareness of being "European" remains as awareness of affiliation to a particular nation -

14 A. Jamróz, Demokracja wspótczesna, Białystok 1993, pp. 24-28; cf. A. Antoszewski, Wzorce rywalizacji politycznej we współczesnych demokracjach europejskich, Wrocław 2004, pp. 33-43; cf. M. Król, Bezradność liberałów. Myśl liberalna wobec konfliktu i wojny, Warszawa 2005, pp. 99-108.

15 Thimm, Demokracja, demokratyzacja, prawa człowieka, www.nowakrytyka.phg. pl/article.php3?id_article=94 (updating March 10, 2005).

$16 \mathrm{~K}$. Jendrzej-Gawlicz, Pojęcie wielokulturowości w analizie problemów etnicznych w Europie Srodkowo-Wschodniej, „Sprawy Narodowościowe” 2007, No. 30, pp. 97-105. 
people know that they are Europeans but they also know that they are French, Italians etc.

Even perfectly defined democratic constitution will not solve any conflict and will not survive without a political culture which would sustain its functioning. A development of democratic procedures requires, among others, a time of relative peace, economic prosperity and political stability. It is not possible to combine all these conditions with existence of situations prompted by a conflict. All the more so in that democracy itself is not a way of ruling which is not subjected to crisis. The majority has to impose upon itself limits in deciding about the most important for people matters and it cannot deny rights of minorities for any reason. But what to do when an ethnic conflict takes on an extreme form? That means when it reaches a level of dispute which cannot be curbed even with democratic standards. There are so many solutions as many people who try to face it.

An obstacle of lawlessness is supposed to be a guarantee of human rights but obedience to these rights depends on majority's good will and reason ${ }^{17}$.

So a question if it is allowed to interfere in internal affairs of a country gains the answer by stating that there are rights which do not know state's boundaries and which are not allowed to be changed, even by a democratic majority. Because in this case a whole humanity is a legislator not just a little part of it. ${ }^{18}$ Do all countries, does a whole humanity is driven by the same system of values? So who should watch over obedience of the values? If we presume that breaking of human rights is a sufficient right to interfere, the right to interference in country's internal affairs by the

\footnotetext{
17 Problemy społeczne w grze politycznej, J. Królikowska (ed.), Warszawa 2006.

18 The are few contracts that can be strongly categorized as universal, e.g. human rights - The United Nations Convention on the Rights of the Child 192 ratifications, the Geneva Conventions on the protection of victims of war 191 ratifications, on fighting racism 168, most of the other pacts $147-149$ but decided majority several dozen counties ratifying countries, out of 12 conventions on terrorism 56-176. Outside the circle of contracts' sides there were members of the United Nations Security Council eg. the Kyoto Protocol, the Convention on a ban on the use of landmines and Status of the International Criminal Court.
} 
international community can be justified. ${ }^{19}$ Now other questions have to be answered - when are countries, acting individually or in cooperation with others, entitled to use coercive measures and, particularly, to undertake military action against another country - not on account of selfdefense and not to remove a severe danger to a traditionally understood international peace and safety but to protect people at the territory of the country?

This matter has been a subject of countless debates in the 1990s for a whole decade. The most important cases - those when the interference took place as well as those when it did not happen - have been the centre of attention, unfortunately only for a while. None of the cases has been handled in a proper way and in none of them actions have been taken with an iron fist. Total fiasco of the international intervention in Somalia in 1993 pathetically inappropriate reaction to genocide in Rwanda in 1994; helpless presence of UN's armed forces which in 1995 did not prevent from ethnic cleansing in Srebrenica in Bosnia and Herzegovina; and then NATO's intervention in Kosovo undertaken without United Nation Security Council's approval in 1999. Every one of these serious cases caused strong international controversies, however, usually too late to have been useful. Every time intellectual ferment was not strong enough to establish basic rules concerning, among others, the role and scope of responsibility of the United Nations and limits of country's sovereignty. In 1999 and again in 2000, the Secretary-General of the United Nations appealed to the United Nations General Assembly to find the answers for these complicated dilemmas. Kofi Annan put the issue forward as strongly as possible: "(...) If a humanitarian intervention is indeed an unacceptable violation of a sovereignty, how in that case should we react to events similar to those in Rwanda and Srebrenica - to a really serious and systematic breaking of human rights which strikes the very idea of our common humanity?"20

\footnotetext{
19 P. Mazurkiewicz, Przemoc w polityce, Warszawa 2007, pp. 143-144.

20 Responsibility of providing defence http://www.nato.int/docu/review/2002/issue4/ polish/analysis.html (20.01.2003).
} 
Despite everything it seems that as the international community more and more often we are able to solve and minimize some of emotional, cultural, economic and political problems. It does not mean at all that we will not wrestle with them still for the next years of the $21^{\text {st }}$ century. On a social level we cannot overcome our weaknesses. We often cannot function in a proximity of other people, different than we are and we often create conflict methodically. Locke presumed that state as just a real phase in a human development and clearly stated that "all people are in this phase naturally and they will stay in it until, on the strength of their own agreement, they will become members of a political society." 21

It is hard to rule out the fact that we will still undergo ethnic cleansing which would lead to even bigger division of countries according to national categories but we know that system of relations between and within the countries reach dangerous complications. Very often they create hallmarks of this political hypocrisy, where politics begins there reign duplicity and lies and dignity and humanitarianism are often forgotten. However, it is often remembered to have mouth full of clichés which concern them.

Some people think that differences between dominating cultures or civilizations will be a background of future wrangles. However, conflicts between microcultures or even tensions within them seem to be more probable. ${ }^{22}$ I do not think that nationalism heading not to a "national state" but to a community (defined culturally, religiously and racially) is to be a basic problem in the world policy within the nearest decades. We have to verify a method of providing nations a right to self-determination, it should certainly be a peaceful method. However, we have to remember that mini countries coming into being, proofs of "ethnic correctness", have to manage in a global reality which more and more often is supernational and multicultural at the same time.

The feeling that we do not have any influence on the events breeding a fear of a change, of the future, of the time, is connected with this oblivion and makes dangerous events be ahead of our thought. A thing which is

21 J. Locke, Traktat drugi. Esej dotyczaccy prawdziwych początków, zakresu i celu rządu obywatelskiego, [in:] Dwa traktaty o rzadzie, trans. Z. Rau, Warszawa 1992, p. 173.

22 N. Fergyson, Wojna XXI wieku. Globalny konflikt wybuchnie na Bliskim Wschodzie, „Europa” dodatek „Dziennika” 9.092006, No. 36(127), pp. 10-11. 
a pivot of a relation between the world and the consciousness, a human freedom, has surrendered to distraction. Without it nothing can be build, nothing can be defended and there is no courage to face what a history holds for us. Regaining it would not necessarily make the future calmer but at least it would take place between responsible beings. Gottfried Benn wrote: "we know well that people do not have souls, if they only had a class" 23 .

${ }^{23}$ Quot after: T. Delpech, Powrót barbarzyństwa w XXI wieku, Warszawa 2008, p. 304. 